\title{
JELAJAH SEJARAH MERAUP MAKNA
}

Buku Penghormatan Pdt. (Em) Dr. Mesakh Tapilatu

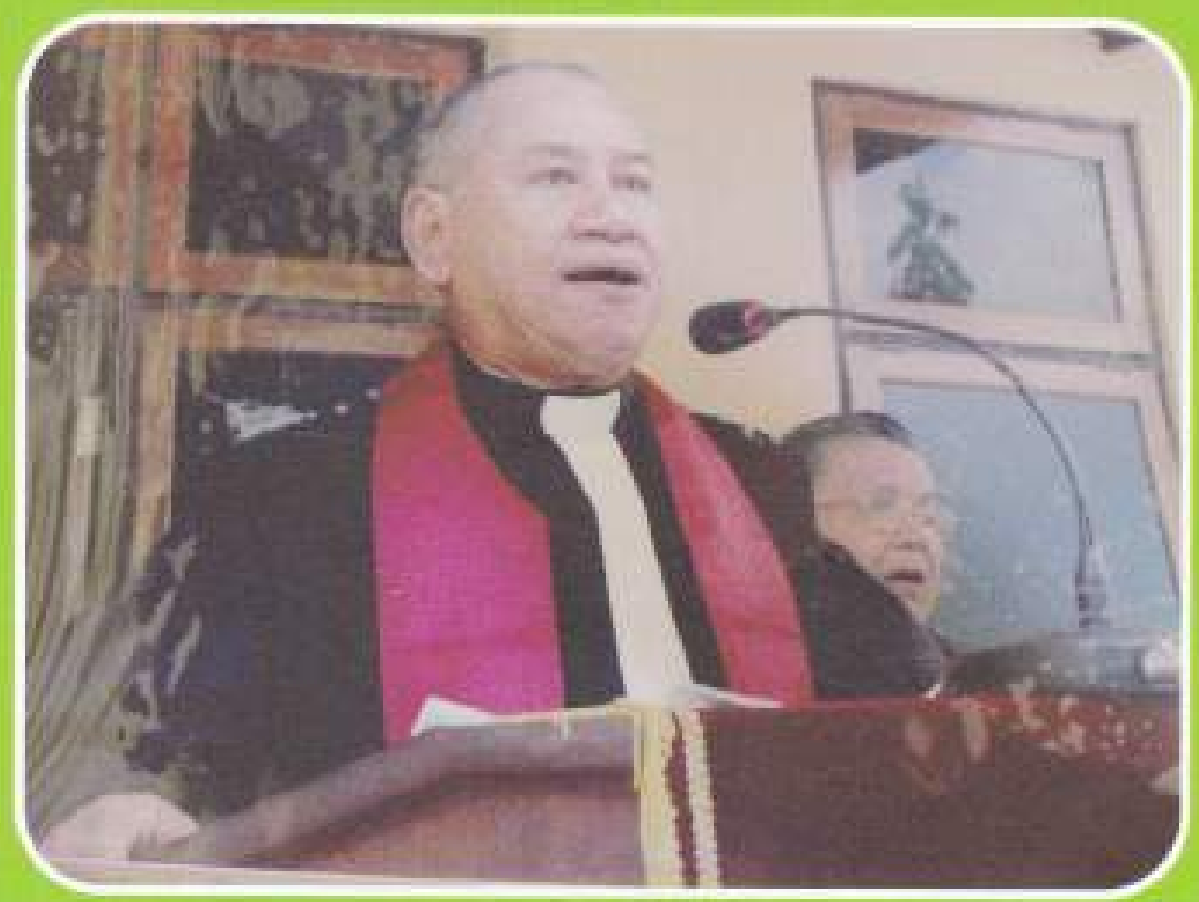

Penyunting

A.M.L. Batlajery, Ph.D

R. Iwamony, Ph.D

Dr. S. Gaspersz, M.A.

R. Dandirwalu, M.Hum

J.R. Saimima, M.A.

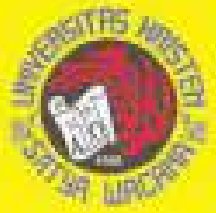

Satya Wacana University Press

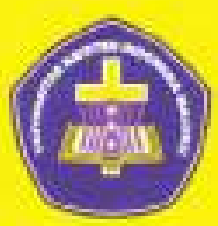

Fakultas Teologi 
Katalog Dalam Terbitan

275.9852

Jel

Jelajah Sejarah Meraup Makna : Buku Penghormatan

Pdt. (Em.) Dr. Mesakh Tapilatu / penyuating

A.M.L. Batlajery, R. Iwamony, S. Gaspersz, R.

Dandirwah, J. R. Saimima.-Salatiga : Satya

Wacana University Press, 2019.

$\mathrm{xx}, 344 \mathrm{p} ; ; 23 \mathrm{~cm}$.

ISBN 978-602-5881-29-9

1. Tapilatu, Mesakh, Priests 2. Maluku-Church history 3. Church and social problems 4 . Church and state S. Pastoral work L. Batlijery, A.M.L. II. Iwamony, R. III. Gaspersz, S. IV. Dandirwalu, R. V. Saimina, J.R.

\section{ISBN 978-602-5881-29-9}

All rights reserved. Save Exception stated by the law, no part of this publication may be reproduced, stored in a retrieval system of any nature, or transmitted in any form or by any means electronic, mechanical, photocopying, recording or otherwise, included a complete or partial transeription, without the prior written permission of the author, application for which should be addressed to author.

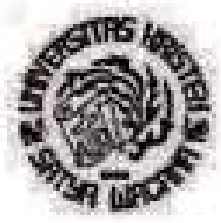

Diterbitkan Oleh:

Satya Wacana University Press

Universitas Kristen Satya Wacana

J1. Diponegoro 52-60 Salatiga 50711

Telp (0298) 321212 Ext. 229, Fax. (0298) 311995 


\section{DAFTAR ISI}

Sambutan Dekan Fakultas Teologi UKIM iii

Kata Pengantar. $v$

Bagian I. Jelajah Sejarah

Jan S. Aritonang

Menetapkan Tanggal Lahir (Hari Jadi) Gereja Bagaimana?

Th. Van den End

VOC dan Umat Kristen Maluku:

Kisah Anak Itik yang Buruk Rupa

Christian de Jonge

Sejarah Teologi Protestan Belanda serta

Pengaruhnya pada Kekristenan

Protestan di Indonesia pada Abad ke-19

dan ke-20, terutama setelah 1918

Johan R. Saimima

Keunikan Sejarah: Jelajah Pemikiran

Dr. M. Tapilatu dalam Mengajarkan

Sejarah Gereja. 63

Steve Gaspersz

Perebutan Hegemoni Blambangan:

Konstruksi Identitas Keagamaan

dan Politik Kolonialisme. 


\section{Bagian II. Jelajah Isu Berteologi}

Agustinus M.L. Batlajery

Teologi Calvin dan Gereja Protestan Maluku

Ebenhaizer 1. Nuban Timo

Perempuan Sebagai Imam Tertahbis dalam

Persepsi Katolik dan Protestan

(Makna Reformasi Abad ke-16 bagi

Penerimaan Perempuan dalam Jabatan Imam)

Robert Patannang Borrong

Pengelolaan Lingkungan Berwawasan

Kemanusiaan.

Bambang Subandrijo

Sebuah Kristologi Monoteistis:

Telanh eksegetis-kontekstual-historis

atas hymne Yesus dalam Kolose 1:15-20.

\section{Bagian III. Jelajah Menggereja Dalam Konteks}

H.H. Hetharia

Korupsi: dulu biasa, sekarang luar biasa!

T.A. E. Relmasira

Karakter Pendidikan Kristiani

N.N. Souisa

Kerugian-kerugian Masyarakat

Maluku Tengah Kristen pada Masa

Kolonial (Perspektif Pendidikan Kristiani) 
Margaretha M. A. Apituley

Menjadi Gereja yang Hidup:

Berteologi dalam Konteks

'Konflik Agama' di Tolikara.

Juliana Agusthina Tuasela

Evolusi Agama: Kajian Sejarah

Perkembangan Agama dari

Perspektif Pluralisme._._..................................279

Bagian IV. Jelajah Sejarah Hidup dan Kerja Pdt.

(Em.) Dr. M. Tapilatu

Riwayat Hidup dan Pekerjaan:

Pdt. (Em.) Dr. M. Tapilatu..........................................303

Pdt. (Em) Dr. M. Tapilatu Dalam Kenangan..........309 


\title{
Korupsi: dulu biasa, sekarang luar biasa!
}

\author{
H. H. Hetharia
}

\section{Pengantar}

Salah satu masalah yang terus dipercakapkan dalam kehidupan kita setiap hari akhir-akhir ini, yaitu masalah korupsi! Ya korupsi, kata sekaligus masalah yang selalu terdengar dalam pergaulan bermasyarakat kita, hampir pada seluruh lapisan masyarakat, dari anak-anak hingga orang lanjut usia, dari rakyat jelata hingga para elit bernegara, khususnya di Indonesia. Maraknya percakapan terhadap masalah korupsi ini paling tidak didorong oleh dua hal: pertama, korupsi merupakan masalah etik-moral, masalah yang tidak dibenarkan secara etik-moral khususnya oleh agama. Oleh karena itu, ia bukan hanya masalah hukum karena melanggar hukum tetapi terlebih merupakan masalah etik-moral agama, sehingga menjadi percakapan warga masyarakat yang sekaligus penganut agama-agama di Indonesia. Agama apapun mengajarkan bahwa korupsi sebagai dosa dan tidak sesuai dengan kehendak Tuhan Sang Pencipta. Kedua, korupsi telah ada dalam sejarah masyarakat Indonesia sejak zaman dulu hingga kini. Yang berbeda adalah korupsi pada masa lampau scring dilihat sebagai masalah yang biasa bahkan dianggap sebagai kebiasaan yang wajar, namun sekarang disikapi khususnya oleh pemerintah sebagai masalah yang luar biasa (extraordinary crime) sehingga ditempuh langkah-langkah luar biasa untuk mengatasinya. Sebagai masalah yang luar biasa sekarang ini, baik dalam hal pencegahan, pengungkapan kasus-kasus korupsi maupun dalam hal penindakan, korupsi terus menjadi percakapan hingga sckarang ini.

Tulisan ini akan menelusuri masalah korupsi ini dalam sejarah umat manusia, korupsi yang scjak dulu merupakan hal yang biasa dan terjadi di mana-mana. Namun, 
di masa kini telah menjadi hal yang luar biasa bahkan sebagai extraordinary crime di banyak negara di dunia, termasuk di Indonesia. Masalah korupsi ini kemudian secara singkat akan dikaji secara teologis-etis.

\section{Korupsi dalam Sejarah Manusia di Masa Lalu: hal yang biasa.}

Fenomena korupsi telah berakar jauh di masa lampau dalam sejarah umat manusia dan telah terjadi pada hampir semua sejarah bangsa di dunia. Dapat dikatakan bahwa sejarah korupsi bermula sejak awal kehidupan manusia bermasyarakat, yakni pada tahap di mana organisasi kemasyarakatan yang rumit mulai muncul.' Korupsi akan timbul jika dalam suatu masyarakat yang telah terorganisasi tidak ada pemisahan yang tegas antara milik masyarakat dengan milik pribadi. Biasanya yang sering melakukan pengaburan antara milik masyarakat dengan milik pribadi ini tentulah para penguasa di dalam suatu masyarakat. ${ }^{2}$

Untuk menelusuri sejarah korupsi di masa lampau, dapat dirujuk tulisan S.H. Alatas yang memperlihatkan beberapa catatan kuno mengenai masalah korupsi, khususnya korupsi yang terjadi sehubungan dengan penyuapan terhadap para hakim dan tingkah laku para pejabat pemerintah. Catatan-catatan kuno tentang korupsi ini, khususnya yang terjadi dalam sejarah bangsa-bangsa yang telah mengalami kemajuan peradaban di masa lampau, seperti Mesir, Babilonia, Ibrani, India, Cina, Yunani dan Romawi kuno, termasuk Indonesia. Masalah korupsi dalam sejarah peradaban bangsa-bangsa dimaksud, secara ringkas dikemukakan di bawah ini.

1.

' Alatas, Korupst, Sfart. Sebah don Fungsi (Jakarta: LP3ES, 1987), hlm.

${ }^{2}$ Mochtar Lubis dalam Mochear Lubis dan James C. Scot (penyunting), Bunga Rampai Korupsi (Jkarta: LP3ES, ot. ke-3 1995), hlm. xvi. 
Di Babilonia, ${ }^{3}$ Raja Hammurabi yang berkuasa sekitar tahun $1200 \mathrm{SM}$ memerintahkan seorang gubernur provinsi untuk menyelidiki suatu perkara penyuapan. Sedangkan Shamash, seorang raja Assiria (sekitar tahun 200 SM) menjatuhkan pidana kepada scorang hakim yang menerima suap. Hukum Hammurabi mengancam beberapa bentuk korupsi tertentu yang dilakukan oleh para pejabat pemerintah dengan hukuman mati.

Sementara di Israel (Ibrani), masalah korupsi telah mendapat perhatian dalam sejarah Israel baik pada zaman sebelum kerajaan maupun pada zaman kerajaan (monarki) yang disoroti oleh para nabi. Kritik para nabi Israel terhadap permasalahan korupsi dalam kehidupan bangsa Israel dapat ditemukan dalam Alkitab, khususnya Perjanjian Lama. Praktik korupsi mulai disinggung dalam kehidupan para raja Israel, baik Israel (Utara) maupun Yehuda (Selatan). Hal ini misalnya dapat kita lihat ketika Raja Yosafat (raja Yehuda: 870-848 SM) mengangkat para hakim yang bertugas untuk mengadili dan memutuskan perkara di semua kota Yehuda, ia berpesan "Pertimbangkanlah apa yang kamu buat, karena bukanlah untuk manusia kamu memutuskan hukum, melainkan untuk Tuhan, bertindaklah dengan seksama, karena berlaku curang, memihak ataupun menerima suap tidak ada pada Tuhan, Allah kita." (2Taw. 19:6,7). Di sini jelas terlihat bahwa Yosafat menentang praktik suap dan mengingatkan para hakim yang diangkatnya untuk tidak menerima suap (Ibr. shachad), berdasarkan pandangan teologis pada sifat dan karakter Allah yang tidak menerima suap seperti yang terdapat dalam Ulangan 10:17.

Persoalan korupsi dalam bentuk suap atau sogok ini mulai terjadi dan merambat kehidupan Israel tatkala mereka mengalami zaman kemakmuran sekitar abad ke-8 SM. Zaman kemakmuran yang dialami Israel ini mengakibatkan timbulnya berbagai bentuk ketidakadilan di dalam masyarakat termasuk perilaku korupsi (suap) di kalangan

${ }^{3}$ Alatas, Konupa, Syar, Sebab dan Fungsi, hlm. 1. 
para pemimpin Israel. Keadaan tersebut mengharuskan para nabi muncul dengan kritik kenabian mereka seperti yang disampaikan oleh Amos (5:12), Yesaya (1:23; 5:23) dan Mikha $(3: 11 ; 7: 3)$. Para nabi Israel ini mengkritik berbagai bentuk ketidakadilan termasuk suap sebagai persoalan yang serius dan merupakan praktik yang tidak dikehendaki oleh Allah.

Di India, ${ }^{4}$ hukum Manu menetapkan bahwa raja hendaknya jangan berbuat serakah, jangan memeras dalam memungut pajak. Ia harus mengangkat pejabat yang jujur untuk memungut pajak. Raja yang menindas masyarakatnya harus dibunuh berikut anggota keluarganya. Para pejabat yang korup yang menerima uang suap dari orang-orang desa harus diusir dari kerajaan, dan harta kekayaan mereka disita. Perdana Menteri Maurya yang termasyhur (abad ke-4 SM) menaruh perhatian besar terhadap korupsi dan akibatnya pada pemerintahan dan negara. Perlawanan terhadap praktik korupsi tidak saja dan para penguasa India, tetapi juga dari agama. Agama Hindu yang merupakan mayoritas di India selalu menentang dan mengutuk praktik suap, kerakusan, dan cara memperoleh harta milik secara salah. Ajaran agama Hindu tersebut menjadi inspirasi bagi para penguasa untuk memberantas korupsi di India.

Di Yunani, ${ }^{5}$ masalah korupsi mendapat perhatian yang jauh lebih besar oleh para penulis Yunani kuno dari pada penulis lain di negara manapun pada masa itu. Hal ini disebabkan oleh makin besarnya pengaruh demokrasi dan adanya dukungan publik untuk menjatuhkan martabat lawan politik. Dalam pertentangan antara berbagai partai, masalah korupsi menjadi penting. Ada contoh yang menarik yang patut dikemukakan di sini, yakni kisah peradilan Kimon pada tahun 463 SM. Ia merupakan seorang prajurit dan negarawan terkemuka Athena yang diadili atas tuduhan melakukan pengkhianatan menerima suap dari Alexander raja

${ }^{4}$ Ibid., hlm. 2-3.

Shid., hlm. 4. 
Makedonia. Jaksanya adalah seorang negarawan terkenal, Pericles. Namun Kimon dibebaskan dari tuduhan karena ia menggunakan kekayaannya untuk merebut hati orang miskin. Sementara Pericles yang tidak mempunyai sarana seperti itu memakai cara lain untuk merebut massa, yakni menggunakan kekayaan negara untuk mendapatkan dukungan massa. Dalam waktu singkat, dengan mengadakan pesta-pesta umum, memberi imbalan kepada para juri dalam pengadilan dan berbagai bantuan serta hadiah lain, ia berhasil menyuap rakyat dalam jumlah besar-besaran dan merebut dukungan mereka dalam serangannya terhadap Dewan Areopagus. Sejak saat itu, penyuapan menjadi terorganisasi terhadap para hakim. Korupsi sering dilakukan orang di Yunani secara luas namun tidak pernah disetujui oleh sistem nilai Yunani.

Dalam sejarah Yunani, korupsi menjadi pusat perhatian sebagai akibat dari pertentangan kelompok dalam suatu sistem yang mengandung unsur-unsur demokrasi. Pihak-pihak yang berlawanan memanfaatkan persoalan korupsi ini. Selain itu, ketidakadilan yang berlangsung sebelumnya juga menentukan reaksi terhadap korupsi. Tirani dan korupsi yang terjadi diperkuat oleh adanya tirani dan korupsi sebelumnya. Penyelewengan yang terjadi sebelumnya, jabatan yang diperdagangkan, pemungutan pajak yang berlebihan, penyitaan hak milik, penggunaan uang negara untuk menyenangkan hati rakyat, penyuapan terhadap hakim, penahanan orang yang tidak berdosa untuk mendapatkan uang pembebasan, adalah praktik-praktik yang kemudian melahirkan penyelewengan berikutnya. Sedangkan Aristoteles tidak mengakui adanya praktik korupsi terhadap para pemilih di Yunani seperti yang terjadi di Romawi, tetapi menunjuk pada jabatan-jabatan penting yang 'dapat dibeli' seperti yang terjadi di Kartago. ${ }^{6}$ Aristoteles menjelaskan: "It is natural that a man should make money of his office if he

${ }^{6}$ R.H. Murray, "Corruption and Bribery" dalam James Hastings (ed.), Encyclopaedia of Religion and Ethics (Vol. IV), (New York: Charles Scribner's Sons, 1951), hlm. 123. 
has to pay for it". Jabatan dapat diperoleh di Kartago hanya dengan melakukan suap.

Di Romawi, praktik korupsi (suap) telah muncul paling tidak sejak abad ke-6 SM, khususnya yang dilakukan oleh para kandidat dengan menyuap rakyat pemilihnya (dalam bentuk pemberian gandum maupun berbagai pertunjukan seperti pertunjukan gladiator), dalam persaingan untuk menjadi anggota Senat. ${ }^{7}$ Sejarah Romawi juga mencatat sejumlah hukum yang dihasilkan untuk memerangi dan memberantas praktik korupsi (suap) tersebut. Hukum yang pertama dibuat pada tahun $432 \mathrm{SM}$, kemudian diikuti oleh hukum-hukum yang berikutnya, seperti: lex Poetelia (358 SM), tex Cornelia Baebia (181 SM), tex Gabinia dan lex Maria (139 SM), lex Aelia Calpurnia (67 SM), dan lex Tullia de ambitu (63 SM) yang dibuat pada masa Cicero, dan lex Licinia de Sadalicius. Walaupun sejarah Romawi menunjukkan betapa kuatnya upaya pemberantasan praktik korupsi (suap) lewat sejumlah hukum yang dihasilkan tetapi dalam praktiknya efek yang dihasilkan oleh hukum-hukum tersebut sangat kecil dan tidak dapat memberantas sepenuhnya praktik korupsi di Romawi. Hal ini disebabkan adanya semangat imperialisme dan semangat partai di kalangan masyarakat pemilih Romawi yang menyebabkan praktik suap tetap diterima dan terus berkembang di sana. ${ }^{8}$ Intensitas dan keragaman korupsi di Romawi dapat dikatakan lebih besar daripada di Yunani. ${ }^{9}$ Selama tiga puluh tahun pertama abad ke-2 SM, Romawi mengalami berbagai perubahan ekonomi, politik, sosial dan pertanian. Terjadilah peningkatan kekayaan para jenderal dan prajurit dengan cepat, dan juga negara, dari rampasan sebagai hasil kemenangan perang. Berbagai bangunan dibuat oleh negara, sehingga terjadilah mobilitas sosial yang hebat di kala itu. Kelas-kelas orang kaya baru mulai muncul. Kelompok baru

${ }^{7}$ Jbid., hlm. 121.

${ }^{8}$ lbid, hlm. 121-122.

?Alatas, Konupai, Sifar, Sebab dan Fungri, him, 6-8. 
para kapitalis yang kaya secara bertahap muncul dan menguasai keadaan. Kelompok yang beruang ini kemudian sangat berpengaruh dalam kegiatan pemilihan senat, pembagian saham, dunia usaha dan keputusan pengadilan. Akibatnya, korupsi menerobos wibawa pengadilan tertinggi. Faktor lain yang mendorong berkembangnya korupsi ialah perubahan atas kekuasaan pengadilan, di mana kekuasaan pengadilan dialihkan ke tangan Senat.

Salah satu kasus korupsi pada zaman Romawi yang patut disebutkan adalah perkara korupsi yang dituntut oleh Cicero atas nama masyarakat terhadap Gaius Verres, seorang Gubemur Provinsi Sisilia pada tahun 73-71 SM. Selama peradilan, Verres dengan menggunakan uangnya berhasil menyogok banyak senator yang duduk sebagai anggota majelis hakim, dan berhasil melarikan diri dari Roma ke Massilia sebelum keputusan dijatuhkan. la hidup di sana dalam kemewahan sampai terbunuh pada tahun 43 SM atas perintah Marcus Antonius. Kasus Verres ini merupakan kasus yang paling menonjol dan luar biasa menarik dalam sejarah Romawi, baik dalam hal kerakusannya maupun luas cakupan korupsinya. Hampir tidak ada jenis kejahatan korupsi yang belum pernah ia lakukan: pemerasan, perampokan, penyuapan, menjual jabatan, makan riba, dan juga memalsukan wasiat orang yang sudah mati. Fakta bahwa Gaius Verres melakukan korupsi selama berkuasa sebagai gubernur, merupakan fakta korupsi di kalangan birokrat pemerintah (gubernur maupun stafnya) pada kekaisaran Romawi, sehingga ada yang mengatakan bahwa "Pada abad ke-1 SM, alih tugas ke provinsi scbagai gubernur atau sebagai anggota staf gubemur dianggap sebagai cara tercepat untuk menjadi kaya". ?o

Korupsi di kekaisaran Romawi begitu merajalela schingga telah menjadi praktik yang diterima sebagai suatu kebiasaan. Paul-Louis ${ }^{11}$ berpendapat bahwa kasus Verres

\footnotetext{
${ }^{10} \mathrm{~N}$. Levis, schygaimana dikutip oleh Alatis dalam ibid., him. 9.

"Paul-Louis, sebagaimara dikutip oleh Alatas dalam ibid., hlm. 11.
} 
bukanlah suatu keistimewaan, masih banyak lagi gubemur yang dikirim ke wilayah-wilayah yang ditaklukkannya dengan kekuatan yang begitu besar schingga mereka melakukan segala jenis perbuatan jahat, dan mereka mampu mengumpulkan atau menambah kekayaan dalam beberapa bulan. Memang ada tindakan-tindakan perlawanan terhadap praktik korupsi yang terjadi di Romawi ini, seperti yang dilakukan oleh Kaisar Diocletianus (301 M), Kaisar Konstantinus (319 M) dan sebagainya, tetapi hasilnya tidak efektif untuk menekan praktik korupsi di Romawi. Korupsi tidak saja terjadi di kalangan penguasa, tetapi juga telah menjadi gaya hidup (way of life) orang Romawi. Korupsi tidak terbatas pada penyuapan yang dikenal sebagai cara untuk membangun dan memelihara keutuhan angkatan perang, dan pada pemerasan di tingkat provinsi yang menjadi kebiasaan para gubernur maupun orang-orang kuat lainnya, tetapi juga mencakup rakyat yang makin lama makin terbiasa dengan menerima suap untuk kesetiaan mereka dalam bentuk makanan dan hiburan dari para penguasa. ${ }^{12}$ Memberi hiburan, makanan dan minuman secara cuma-cuma, dan hadiahhadiah kepada rakyat untuk memperbesar pengaruh dan ketenaran pihak pemberi, merupakan salah satu bentuk penyuapan penguasa kepada rakyatnya yang kemudian menjadi gaya hidup Romawi. Hiburan untuk rakyat ini merupakan sumber korupsi karena mengakibatkan terjadinya pengeluaran besar-besaran. Akibatnya terjadi pemerasan terhadap rakyat di provinsi-provinsi Romawi ${ }^{13}$ Singkatnya, korupsi begitu meluas di kekaisaran Romawi dan telah menguasai serta mempengaruhi badan pengadilan, angkatan perang, dunia usaha, Senat, pergantian kaisar, sistem pemilihan, sistem tuan-hamba, pemerintahan, bahkan juga rakyat Romawi. Karena itu, ada kesimpulan bahwa salah satu

${ }^{12}$ Ibld., him. 25 .

${ }^{13}$ Pbid., hilm 29-31. 
penyebab runtuhnya kekaisaran Romawi adalah korupsi yang telah begitu meluas di kekaisaran tersebut. ${ }^{14}$

Di Cina Kuno, ${ }^{15}$ korupsi merupakan masalah yang sangat parah dan mendapat perhatian, baik dari para bijak yang menentang korupsi maupun dari para kaisar yang menaruh simpati kepada orang yang berusaha memberantas kejahatan korupsi. Korupsi yang terjadi di Cina sering disebabkan oleh terjadinya pergantian penguasa. Berulangkali para menteri dan cendekiawan Cina mengemukakan masalah pertanggungjawaban penguasa untuk memberantas ketidakadilan dan korupsi. Salah satu peluang terjadinya korupsi di Cina adalah peraturan yang dibuat oleh pemerintah, yang seringkali digunakan oleh pejabat yang korup untuk memperkaya diri sendiri, sehingga peraturan tersebut bukannya dapat mengatasi keadaan, tetapi semakin memperparah dan menambah terjadinya praktik korupsi. Dapat dikatakan bahwa korupsi oleh para pejabat pemerintah berlangsung sepanjang sejarah Cina. Para kaisar tidak bersikap sama terhadap korupsi, sedikit saja yang benarbenar cemas dan ingin memberantasnya. Salah scorang kaisar yang patut discbutkan di sini adalah kaisar Hsiao Ching (157 SM). Diceritakan bahwa ia membatasi keinginannya dan menolak hadiah-hadiah atau memperkaya diri sendiri. Ia juga mengeluarkan sebuah dekrit yang mengharuskan para pejabat pemerintah yang menerima makanan dan minuman dari bawahan atau orang-orang yang dibawah perintahnya untuk membayar kembali harganya; jika tidak, mereka akan diajukan ke pengadilan. Demikian pula, barangsiapa sengaja membeli barang dengan harga murah dari rakyat dan menjualnya dengan harga mahal, akan dihukum sebagai orang yang memakan uang suap atau perampok. ${ }^{16}$ Namun sama halnya dengan upaya keras para kaisar yang lain sepanjang sejarah Cina, upaya kaisar Hsiao Ching lewat

\footnotetext{
it Ibid., hlm. 18.

is Ihid, hlm. 43.

${ }^{16}$ Pan $\mathrm{Ku}$, sebugaimana dikutip oleh Aletas dalam ibid, hlm, 49.
} 
dekritnya ini juga tidak membawa hasil yang berarti terhadap pemberantasan korupsi. Hal ini menurut Alatas disebabkan oleh ketidakmampuan untuk menjamin dilaksanakannya dekrit tersebut secara baik ke jenjang pemerintahan yang terbawah. ${ }^{17}$

Upaya pemberantasan korupsi di Cina kuno terus dilakukan oleh para penguasa selanjutnya, baik yang menekankan pada pentingnya perundang-undangan (kaum legalis: para penguasa) maupun yang menekankan pada pentingnya moral/budi manusia (kaum moralis: filsuf Konghucu dan para pengikutnya). Kedua penyebab korupsi ini barulah dapat dilihat secara bersama sebagai satu kesatuan pada zaman Wang An Shih (1021-1086 M), seorang negarawan besar (perdana menteri Dinasti Sung Utara) dan pembaru Cina yang sangat berusaha untuk mengikis kejahatan dan korupsi di zamannya. Menurutnya, dua penyebab korupsi yang selalu tampi adalah: hukum yang buruk dan orang yang buruk. Ia menyatakan, "... sejarah membuktikan, mustahil untuk memastikan tegaknya pemerintahan yang baik dengan hanya mengandalkan kekuatan hukum untuk mengawasi para pejabat, apabila mereka ini tidak terdiri dari orang-orang yang tepat untuk jabatan mereka,"18 Wang An Shih juga menekankan imbalan gaji yang pantas diterima oleh para penyelenggara negara agar mereka tidak bertindak sesuka hati dan korup. la menegasakan, "Dengan bertambah banyaknya tugas, gaji mereka diperbesar agar menjamin bahwa tingkat gaji yang mereka terima tetap membuat mereka jujur, menghormati martabat pribadi, dan bebas dari korupsi." ${ }^{\text {'9 }}$ Sekuat-kuatnya Wang An Shih berusaha memberantas korupsi, ternyata usahanya ini tidak dilanjutkan oleh para penerusnya, sehingga praktik korupsi kembali merajalela di Cina. Korupsi dan pemerasan semakin menjadi-jadi, tidak saja pada waktu

17 Bovd. him. 51 .

"H.R. Willinmson, sebagaimana dikutip oleh Alatas dalam ibid, blm.

77.

${ }^{19}$ Bbid. him. 79. 
peralihan penguasa, tetapi juga di saat terjadinya musibah berupa banjir, paceklik, ataupun peperangan, schingga rakyat semakin menderita karena menjadi korban pemerasan oleh penguasa. Yang paling buruk adalah penipuan dalam sidang peradilan di mana orang yang miskin selalu menjadi kurban, sedangkan orang yang kaya dapat menyewa advokat. ${ }^{20}$

Selain sejarah korupsi pada zaman kerajaan/ peradaban kuno di dunia yang telah kita bahas di atas, ada baiknya jika kita melihat pula secara sepintas sejarah korupsi di Indonesia, baik pada zaman kerajaan-kerajaan Jawa kuno, zaman penjajahan (kolonial) dan budaya Maluku yang sangat berhubungan dengan tesis ini, maupun pada zaman kemerdekaan Republik Indonesia, sebagai berikut:

Zaman kerajaan-kerajaan Jawa kuno dengan budayanya dipilih sebagai representasi sejarah korupsi di Indonesia pada masa lampau, sebab walaupun Indonesia merupakan negara multietnis, orang Jawa telah merupakan komunitas suku inti di Indonesia dan budaya Jawa telah berpengaruh besar dalam membentuk budaya Indonesia. ${ }^{21}$ Apalagi setelah kemerdekaan, Indonesia dipimpin oleh Soekamo dan Socharto, keduanya dinilai telah mempraktikkan format khusus kepemimpinannya yang bisa dilihat sebagai bagian dari tradisi raja-raja jawa. ${ }^{22}$ Dengan demikian, upaya untuk menjelaskan sejarah dan budaya korupsi di Indonesia harus dilihat dalam hubungan dengan adanya kebiasaan-kebiasaan Jawa kuno tersebut.

Menurut Fiona Robertson-Snape kebiasaan-kebiasaan itu adalah berupa pemberian hadiah (upeti) kepada para pemimpin (penguasa/priyayi). ${ }^{23} \mathrm{Hal}$ ini dapat menjelaskan mengapa suap sangat marak, sebab pemberian hadiah seperti

${ }^{20}$ Etienne Balasz, schagaimana dikutip oleh Alatas dalam ibid., hlm. 85 .

21 Fiona Robertson-Snape, Korupsi, Kolusi dan Nepotisme di Indonesia" dalam Pranotio U. Tanbowi dkk (eds.), Menbasmi Kanker Konupsi (Jakarta: PSAP Muhammadlyah, 2005), hlm. 30.

${ }^{22} \mathrm{Hal}$ ini ditegaskan olch Ben Andorson sebagaimana yang dikutip oleh Fiona Roberteon-Srape dalam Pramono U. Tanthosi dkk. (eds.), ibid.

${ }^{23} \mathrm{Jbid}$, hlm. 31. 
itu merupakan norma bisnis di Indonesia dan tidak harus dianggap korupsi. Demikian juga dengan konsepsi kekuasaan orang Jawa seperti sistem hierarki dan patrimonial, itu dapat menjelaskan tingginya tingkat korupsi. Dalam sistem kekuasaan patrimonial (menurut warisan dari ayah) yang berlaku pada kerajaan Jawa kuno, semua kekayaan kecuali hal-hal pribadi merupakan milik penguasa. Sistem patrimonial ini ternyata tidak hanya berlaku di kerajaan, tetapi juga berlaku di desa-desa yang merupakan basis pemerintahan sipil di Jawa. Theodore M. Smith menjelaskan bahwa di desa-desa tersebut tidak diadakan pembedaan antara uang yang masuk dan yang tidak masuk ke dalam kas negara; kepala desa yang tidak digaji memungut pajak, membayar untuk diri sendiri apa yang mereka rasakan patut untuk mereka dan memakai sisanya untuk keperluan dess. ${ }^{24}$

Sedangkan Onghokham menilai bahwa dalam sejarah Jawa persoalan pemungutan pajak dan kesewenangan para pejabat pada tingkat menengah dan bawah, seperti para demang, bekel, dan khususnya para penjaga pintu gerbang jalanan (toll gates), menyebabkan pemberontakan antara lain pemberontakan Diponegoro (1825-1830). ${ }^{25}$ Dalam arsip-arsip Belanda menurut Onghokham, lebih banyak protes terhadap kesewenangan dan korupsi (penghilangan uang pajak dan lain-lain) dari sang lurah daripada terhadap bupati. Ia menjelaskan berbagai ketidak- efisienan dalam sistem finansial kerajaan Mataram (abad ke-17 M) sebagai berikut:

Di Mataram, tidak ada pusat yang mengurus keuangan negara atau tidak ada sentralisasi keuangan Setiap jabatan berdiri sendiri dan otonom, yang satu tidak ada hubungan dengan yang lain. Sedangkan setiap pejabat harus membiayai baik jabatan umumnya dan pribadi, dari sumber penghasilan jabatan tersebut. Di sini jelas tidak

${ }^{14}$ Theodore M. Smith, "Kerupsi, Tradisi din Perubahan di Indonesia" dalam Mochtar Lubis dan James C. Scott (peny.), Korupoi Politik (Jakarta: Yayasan Obor Indonesia, 1993), hlm. 55.

${ }^{75}$ Onehokham. "Tradisi dan Korupsi" dalam Mochtar Lubis dan James C. Scott (peny.), Bunga Rampat Kongasi, hlm. 121. 
ada pemisahan antara kepettingan pribadi dan umum. Karena itu semua jabatan adalah juga pengumpulan dana atau upeti (pajak) dari mana kehidupan pribedi dan jabatan harus dibiayai. Setiap pejabat diberi hungguh (kedudukan) oleh raja. [ukurannya] dalam jumlah orang (cacah). Para cacah ini harus menyerahkan upeti dan tenaga kerja (bakti) pada pemegang hengguh. Dari sumber penghasilan ini, pemegang lungguh membiayai jabatan dan kehidupannya. Bagi raja, pembagian hungguh dengan penugasan mencari dana pada si pemegang lungyuh atau pejabat, merupakan sistem pengumpulan pajak dan upeti. Sebab biasanya setiap pemegang lungguh juga harus menyerahkan upeti dan sebagian dari penghasilannya kepada raja. Upeti tersebut dapat berupa hasil agraria, uang dan juga tenaga kerja dan militer dari para cacahnya. ${ }^{26}$

Sistem hierarki dan patrimonial dengan penyerahan upeti dari bawahan kepada atasan yang dipraktikkan di kerajaankerajaan Jawa kuno ini tentu merupakan lahan subur berkembangnya praktik korupsi, yang terus diwariskan hingga Indonesia menjadi negara merdeka sekarang ini.

Perilaku korupsi yang terjadi di Indonesia tidak hanya karena pengaruh budaya kerajaan-kerajaan Jawa kuno, tetapi juga karena pengaruh kebiasaan kolonial. Theodore $\mathrm{M}$. Smith $^{27}$ menjelaskan bahwa sebelum tahun 1800 Dutch East India Company (VOC) memberikan contoh tingkah laku korupsi yang keji kepada orang Indonesia, yaitu karena gaji yang rendah menyebabkan para pejabatnya melakukan pencurian (korupsi) dari perusahan tersebut, sehingga mereka menjadi pejabat-pejabat yang kaya. Praktik korupsi ini terus berlangsung pada zaman kolonial. Clive Day, sebagaimana yang dikutip oleh Smith, menjelaskan bahwa:

${ }^{26} \mathrm{lbSd}$, hlm. 129-130. Kata [ukuraanya] ditambahkan okh penulis untak menyambungkan kalimat di depan, beberaps kalimak yang tidak dikutip dan kalimat yang mengikutinya.

${ }^{27}$ Theodore M. Snith, "Konupsi. Tradisi daa Perubahan di Indonesia" dalam Mochas Lubis dan James C. Scott, Konipsi Polliki, hlm. 52. 
Lenyapnya kekuasaan kompeni dan kedatangan gubernur jenderal Belanda pada pergantian abad ke-19 berakibat meluasnya praktik terlarang (korupsi) yang tidak dapat dihindarkan. Dengan bertambah luasnya peraturan dan pengendalian kolonial, pejabat Eropa maupun pribumi yang bersuka-ria dalam penyalahgunaan yang nyata, tidak saja menikmati persentase khusus yang menjadi hak mereka, akan tetapi juga bagian dari sebagian besar sumber yang melewati tangan mereka. Ketika jasa dan pembayaran tradisional yang harus diberikan kepada para pejabat pribumi yang aristokratis dihapuskan dan diganti dengan gaji yang dibayar oleh Belanda, pejabat pribumi tidak mempunyai pilihan lain kecuali memakai cara-cara tidak sah kalau mereka ingin mempertahankan taraf hidup yang sudah menjadi kebiasaan mereka. ${ }^{2 t}$

Perilakú pejabat yang korup, baik akibat budaya Jawa maupun karena pengaruh kebiasaan kolonial, telah membentuk perilaku hidup orang Indonesia hingga ke zaman kemerdekaan. Wakil Presiden RI yang pertama, Moh. Hatta, telah menulis tentang praktik korupsi pada masa-masa awal setelah kemerdekaan RI ini, sebagaimana dikutip olch Gunnar Myrdal:

Corruption mus riot through our socicty; comption has also infected a great many of our government departments... Workers and government employees, whose wages and salaries are no longer adequate for their daily needs, are being exploifed by enterprising adventurers who want to get rich quickly ... This is why businessmen who remain faithful to economic morality are constantly being pushed backward. Bribery and graft have become increasingly common, to the detriment of our community and our country. Each year the government loses hundreds of millions of rupiahs in duties and taxes which remain

24 lhid. Smith juga mengutip beberapa sumber yang menunjukkan adanya pengaruh kebiasaan-kebiasaan kolonial Belanda yang menularkan praktik korupsi bagi crang Indonesia. 
umpaid as a result of fraud and smugging, both illegal and legai:"20

Ternyata bahwa setelah zaman kemerdekaan, perilaku korupsi makin melanda bangsa Indonesia. Korupsi telah meresap ke segenap lapisan masyarakat, dan menjangkiti semua departemen pemerintah. Praktik suap dan sogok menjadi makin lazim schingga merusak masyarakat dan negara. Pemerintah juga makin dirugikan karena praktik pemalsuan dan penyelundupan. Keadaan ini memang masih berlangsung hingga sekarang ini.

Dari sejarah dan latar belakang korupsi pada beberapa bangsa yang telah dipaparkan di depan, ada beberapa kesimpulan yang dapat kita tarik:

a. Praktik korupsi telah terjadi hampir di setiap masyarakat atau bangsa, baik yang berbentuk kerajaan, kekaisaran, maupun yang berdasarkan sistem pemerintahan yang menuju pada sistem demokrasi. Korupsi akan terjadi jika orang cenderung menempatkan kepentingan pribadi di atas kepentingan umum.

b. Korupsi di masa lampau telah menjadi kebiasaan dan menguasai hampir seluruh sendi-sendi kehidupan masyarakat/bangsa tersebut, baik pada level pemerintahan pusat hingga daerah, birokrasi, militer, sistem peradilan, maupun masyarakat umum. Pada bangsa-bangsa tertentu korupsi telah menjadi gaya hidup (way of life) dan dianggap sebagai sesuatu yang wajar dan biasa di masyarakat.

c. Penyebab utama terjadinya praktik korupsi pada suatu masyarakat/bangsa di masa lampau adalah lemahnya hukum (perundang-undangan) dan buruknya moral penyelenggara negara.

${ }^{26}$ Gunnar Myndal, Arian Drama VoLll, (New York: Pantheon, 1968), hlm. 943. Myrdal menempatkan kutipan ini pada catatan kaki. 


\section{Korupsi sebagai masalah luar biasa di masa kini.}

Persoalan korupsi di masa lalu yang dipandang sebagai persoalan biasa, bahkan menjadi suatu kebiasaan dan gaya hidup dalam sejarah bangsa-bangsa termasuk Indonesia, ternyata di masa kini telah dinilai secara kritis dan menjadi masalah luar biasa dari pemerintah bangsa-bangsa di dunia untuk memberantasnya.

Fenomena korupsi ini telah menjadi perhatian dan masalah global. Di mulai dari Perserikatan Bangsa-Bangsa yang telah menetapkan tanggal 9 Desember (2003) sebagai Hari Pemberantasan Korupsi Sedunia, yang ditandai dengan disahkannya United Nations Convention Against Corruption (UNCAC: Konvensi PBB untuk Melawan Korupsi) di markas PBB, New York (AS) pada tanggal tersebut. UNCAC ditetapkan berdasarkan dua prinsip: pertama, korupsi merupakan sebuah kejahatan sosial yang harus diberantas melalui proses peradilan tindak kejahatan; dan kedua, agar proses peradilan tindak kejahatan menjadi efektif, peraturanperaturan harus dibuat, baik secara domestik maupun internasional. $^{30}$ Lahirnya UNCAC ini memperlihatkan keseriusan dunia internasional untuk memerangi dan memberantas praktik korupsi yang telah merambah dan menguasai hampir seluruh belahan dunia, termasuk Indonesia.

Indonesia sebagai salah satu negara yang ikut menandatangani konvensi PBB tersebut telah meratifikasi konvensi ini, yakni dengan dikeluarkannya INPRES Nomor 5 tahun 2004 tentang Percepatan Pemberantasan Tindak Pidana Korupsi. Langkah ini juga ditempuh untuk melengkapi sejumlah langkah strategis yang sebelumnya telah ditempuh oleh pemerintah, guna memberantas korupsi, antara lain dengan ditetapkannya UU RI nomor 30/2002 tentang Komisi Pemberantasan Tindak Pidana Korupsi, UU RI nomor

35 Ian MeWalkes, Mennerangi Konupsi, Seluah Peta Salas untuk Indonesia (Surabaya: Jawa Pos Books, 2006), hlm. 19. Dalam bukunya ini, MeWalters secara luas membahas LNCAC tersebut. 
20/2001 mengenai Perubahan atas UU RI nomor 31/1999 tentang Pemberantasan Tindak Pidana Korupsi, UU RI nomor 28/1999 tentang Penyelenggaraan Negara yang Bersih dan Bebas dari KKN, dsb. Persoalan korupsi ini tentu menimbulkan akibat bagi negara dan masyarakat. Akibatakibat korupsi pernah ditegaskan oleh Presiden RI ke-6 (Susilo Bambang Yudhoyono), yaitu: "Korupsi yang selama ini terjadi secara meluas, tidak hanya merugikan keuangan negara, tetapi juga telah merupakan pelanggaran terhadap hak-hak sosial dan ekonomi masyarakat secara luas, ${ }^{n 11}$ Kita dapat melihat bahwa akibat korupsi, terjadi penumpukan kekayaan pada segelintir orang karena telah mengambil apa yang seharusnya menjadi hak orang banyak, sehingga semakin terjadi kesenjangan antara yang kaya dan yang miskin.

Berbagai langkah strategis yang telah ditempuh oleh pemerintah Indonesia, khususnya setelah tumbangnya Orde Baru (1998) dengan berbagai bentuk perundang-undangannya tersebut, menunjukkan kesungguhan dan keseriusan pemerintah dalam mencegah dan memberantas praktik korupsi di negara ini, yang telah meliputi seluruh sektor kehidupan bernegara dan bermasyarakat, tidak saja di bidang pemerintahan tetapi juga di dunia swasta. ${ }^{32}$ Korupsi di negara kita kini diibaratkan sebagai penyakit yang telah mewabah $h^{53}$, bahkan telah menjadi semacam kanker" dalam seluruh aspek

3) Hal ini ditegaskan oleh Presiden RI dalam sambutannya pada Pencarangan Gerakan Nasional Perkberantasan Korupsi pada 9 Desember 2004 di Istana Negarn Jakarta, yang ditundai dengan dikeluarkamya Instruksi Presides: (INPRES) RI Nomor 5 tahun 2004 tentang Pereepatan Pemberantasan Korupsi. Sambutan das INPRES tersebut telah dibukukan (diterbitkan dan dicetak) oleh Perum Percetakan Negara RI dengan judul Percepatan Pemberantasizn Karwpsi, (Jakarts: Perum Percetakan Negara RL, 2004), hlm. viii.

${ }^{12}$ Mochtar Lubis dalam Mochtar Lubis dan James C. Stott (penyunting), Bunga Rampai Korupsi (Jakarta: L.P3ES, 1988), hlm. x. Hal ini juga disimpulkan oleh Klitgoard, op.eih, hlm $\mathrm{xx}$.

1987), hlm vii, 115

33.H. Alatas, Konspsi, Sifat, Sebab dan Fungsi (Jakarta: LP3ES

14. Sclo Soemardjan dalam pengantar edisi Indonesia terhadap buku Klitgaard, op.cit, hlm. xiv, menegaskan bahwa korupsi merupaknn suatu penyakit 
kehidupan bangsa Indonesia. Praktek korupsi malah dianggap telah menjadi perilaku yang membudaya ${ }^{35}$ dalam kehidupan bangsa Indonesia. Karena itu, korupsi kini mendapat perhatian serius dan menjadi salah satu agenda utama pemerintah untuk segera ditangani. Kesungguhan pemerintah Indonesia untuk memberantas korupsi ini mendapat penekanan dari Presiden RI (Susilo Bambang Yudhoyono). Dalam sambutannya pada pencanangan dimulainya Gerakkan Nasional Pemberantasan Korupsi pada 9 Desember 2004 di Istana Negara Jakarta, Presiden menegaskan: "Hari ini saya mengajak seluruh komponen bangsa untuk menyatakan tekad bersama kita memberantas korupsi. Korupsi adalah tindak pidana atau kejahatan yang harus kita perangi bersama. Tindak pidana korupsi digolongkan sebagai kejahatan yang pemberantasannya harus dilakukan dengan cara-cara yang luar biasa." ${ }^{36}$ Lebih jauh, Presiden juga menandaskan bahwa gerakan pemberantasan korupsi di negara ini haruslah dijadikan sebagai gerakan bersama yang didukung oleh semua komponen bangsa. Ia menyerukan kepada para alim ulama dan tokoh-tokoh agama, kaum cendekiawan, budayawan serta tokoh-tokoh masyarakat lainnya untuk melakukan gerakan moral bersama melawan korupsi. ${ }^{37}$ Upaya pemberantasan korupsi di Indonesia, tidak saja semata-mata menjadi persoalan pemerintah, tetapi lebih dari itu sangat dibutuhkan keterlibatan dan peran aktif seluruh komponen bangsa, tidak terkecuali peran serta lembaga-

ganas yang menggerogoti kesehatan masyarakat seperti penyakit kanker yang setapak demi setapak menghabisi daya hidup manusia.

${ }^{35}$ Lubis dalam Mochtar Lubis dan James C. Stott (penyunting), op.cit., hlm. xvii - xx, menegaskan bahwa korupsi yang telah membudaya di Indonesia bukan saja dalam pengertian korupsi baru saja menjadi kebiasaan dan membudaya dalam perilaku masyarakat kita sekarang ini, tetapi lebih dari itu korupsi telah berakar pada kebudayaan lama bangsa Indonesia, yaitu budaya feodalisme pada zaman kerajaan-kerajaan di Nusantara tempo dulu dengan sistem birokrasipatrimonialnya yang menerapkan sistem upeti, suap, sogok, dsb.

${ }^{36}$ Sambutan Presiden RI pada Pencanangan Gerakan Nasional Pemberantasan Korupsi, dalam buku Percepatan Pemberantasan Korupsi, hlm. viii.

\footnotetext{
${ }^{37}$ Ibid., hlm. ix.
} 
lembaga agama yang sangat bertanggung jawab dalam membina kehidupan etik, moral, dan spiritual umatnya sebagai bagian dari warga negara Indonesia. Baik buruknya moral, etik dan spiritual bangsa ini sangat bergantung pada pembinaan yang dilakukan oleh setiap agama bagi umatnya. Masalah korupsi tidak saja merupakan masalah sosial, ekonomi, budaya, politik atau hukum, tetapi lebih dari itu sebagai masalah moral (etik, spiritual). Maka di sinilah terletak tanggung jawab dan fungsi pembinaan oleh agarna.

Masalah korupsi yang di masa kini telah dijadikan masalah luar biasa tersebut, sehingga disikapi secara serius oleh sebagian besar negara di dunia ini. Memang, kenyataannya masih terdapat negara-negara dengan tingkat korupsi yang tinggi, bahkan kepala negara dan para pejabat pemerintahannya melakukan korupsi. Namun, banyak negara yang telah secara serius meresponi praktik korupsi ini sebagai masalah luar biasa besar, dan ditindak melalui berbagai bentuk hukuman berat, bahkan hukuman mati terhadap para pelaku korupsi sebagai mana tindakan kriminal besar lainnya. China misalnya, telah menerapkan hukuman mati terhadap para koruptor ini sejak masa kepemimpinan perdana menteri Zhu Rongii (1998-2003), dengan ucapannya yang sangat terkenal: "Beri saya 100 peti mati. Sembilan puluh sembilan akan saya gunakan untuk membunuh para koruptor, dan satu untuk saya kalau saya melakukan tindak pidana korupsi". Dengan pencrapan hukuman mati bagi para koruptor ini, menimbulkan efek jera, dan China berangsur-angsur keluar dari peringkat negara-negara terkorup di dunia. Negara kita Indonesia, walaupun telah menyadari bahwa korupsi merupakan kejahatan yang tergolong luar biasa, namun hingga hari ini belum menerapkan hukuman mati terhadap para koruptor, walaupun telah sering terdengar wacana kearah itu (hukuman mati). 
Korupsi sebagai Masalah Teologis-Etis.

"Indonesja Darurat Korupsi", demikian salah satu berita berita utama pada halaman 1 harian KOMPAS 15 Februari 2018. Berita utama ini terkait dengan fenoma penangkapan para kepala daerah di Indonesia yang melakukan tindak pidana korupsi oleh Komisi Pemberantasan Korupsi (KPK). Sejumlah kepala daerah di Indonesia, baik di tingkat provinsi (gubernur) maupun di tingkat kabupaten/kota (bupati/walikota) yang terjaring Operasi Tangkap Tangan (OTT) oleh KPK dalam tahun 2017 dan awal 2018. Berbagai peristiwa penangkapan kepala daerah yang melakukan korupsi tersebut, membenarkan berita utama KOMPAS ini bahwa Indonesia memang sedang berada dalam status darurat korupsi. Korupsi terus menjadi masalah yang tak terselesaikan di negara ini, bahkan semakin memprihatinkan.

Masalah korupsi seharusnya tidak dilihat hanya sebagai masalah hukum, yaitu sebagai perbuatan yang melanggar peraturan negara tetapi lebih dari itu merupakan masalah teologis-etik (moral). Korupsi merupakan masalah etik-moral karena terkait dengan perilaku manusia yang tidak sesuai dengan standar dan tuntutan etik-moral yang berlaku dalam hidup manusia, khususnya umat beragama termasuk agama Kristen. Manusia sebagai makhluk yang memiliki kesadaran etis (kesadaran tentang yang benar-salah dan baikburuk) yang mestinya melakukan kebenaran dan kebaikan, tetapi sering melakukan kesalahan dan keburukan dalam hidupnya, termasuk korupsi. Dengan demikian, persoalan teologis-etis yang mengemuka adalah mengapa manusia melakukan korupsi? Dalam pandangan teologi-etis (Kristen), manusia sebagai ciptaan Tuhan yang mulia, sebab ia disebut sebagai gambar Allah (Imago Dei) yang berbeda dengan hewan. Manusia lebih tinggi derajatnya, sebab ia memiliki kesadaran etis-moral yang mengarahkan dan mengendalikan perilakunya berbeda dengan hewan. Namun, di balik kemuliaannya sebagai makhluk ciptaan Tuhan yang mulia tersebut, manusia adalah makhluk yang berdosa, telah jatuh 
ke dalam dosa. Keberdosaannya tersebut menegaskan hakikat manusia sebagai makhluk yang telah rusak atau telah korup. Hal ini ditegaskan oleh para teolog Kristen, seperti Agustinus dan Calvin.

Para teolog ini, dalam memberikan penilaian terhadap fenomena korupsi ini, umumnya lebih menaruh perhatian pada penyebab (akar) korupsi. Akibat-akibat korupsi tidak menjadi perhatian para teolog, karena akibat korupsi hanyalah merupakan kulit, bagian luar dari persoalan korupsi dan bukan persoalan utama (inti) korupsi. Mengapa manusia itu korup, itulah pertanyaan yang dijawab oleh para teolog. Jawaban atas pertanyaan ini juga yang menurut para teolog akan menjadi entry point upaya peneegahan dan pemberantasan praktik korupsi. Korupsi bermula dari dalam diri manusia itu sendiri. Statusnya sebagai orang berdosa menyebabkan manusia itu korup, dan senantiasa melakukan perbuatan yang merusak (korup) dalam kehidupannya. Korupsi yang dipahami oleh para teolog ini adalah korupsi moral, yakni kehidupan moral manusia yang telah korup (rusak) akibat dosa.

\section{Augustinus}

Augustinus memberikan pandangannya terhadap manusia sebagai makhluk yang telah rusak (korup) dalam perdebatannya dengan kaum Pelagian, yang meyakini bahwa sekalipun manusia itu berdosa, kehendak manusia pada hakikatnya baik dan mampu memilih secara bebas, dosa Adam hanya merusak dirinya dan bukan keturunannya, dosa itu turun kepada angkatan berikutnya bukan karena diwariskan tetapi karena ditiru. ${ }^{38}$ Mereka menolak apa yang diyakini oleh para Bapa Gereja sebagai dosa asali atau dosa warisan (original $\sin$ ). Augustinus menanggapi pandangan kaum Pelagian ini, dengan berpendapat bahwa: kita tidak

38 John Catvin, Instimutes of the Christian Religion, (Translated by: Henry Beveridge), (Grand Rapids: Wm. B, Eerdmans Publishing, 1989), hlm. 
rusak oleh keburukan yang kita ambil dari orang sekitar kita, tetapi kerusakan itu kita bawa sejak dari rahim ibu. ${ }^{39}$ Augustinus menegaskan bahwa kodrat yang kita wariskan telah rusak (korup) "because the nature which begets is corrupt." ${ }^{40}$ Perbuatan buruk di dalam diri manusia menurut Augustinus, termasuk di dalam dirinya semata-mata disebabkan oleh dosa yang ada di dalam dirinya, sebab ia juga merupakan keturunan Adam. Karena Dosa Asali tersebut maka semua manusia yang adałah keturunan Adam telah rusak (korup), hanya Tuhan Allah yang tidak dapat mengalami kerusakan (incorruptible), apa pun keadaan$\mathrm{Nya}^{41}$ Bagi Augustinus, kehendak bebas (the free will decision) di dalam diri manusia merupakan penyebab manusia itu berbuat jahat. ${ }^{42}$ Augustinus menyatakan bahwa kehendak bebas di dalam dirinya untuk melakukan apa yang ia inginkan atau tidak inginkan, merupakan penyebab dosanya. Manusia dengan kehendak bebasnya untuk memilih yang baik dan yang jahat ini diibaratkan oleh Augustinus seperti kuda yang ditunggangi oleh Allah atau lblis. Kata Augustinus:

If God mowns, he, like a temperate and skilful rider, guides it calmly, urges it when too slow, reins it in when too fast, curbs its formardness and over-action, checks its bad temper, and keeps it on the proper course; but if the devil has seized the saddle, like an ignorant and rash rider, he hurries it over broken ground, drives it into ditches, dashes it over precipices, spurs it into obstinacy or fury. ${ }^{73}$

Karena itu, tergantung pada manusia tersebut sendiri untuk memperhatikan isyarat yang mengendarai kehidupannya, Allah atau iblis dengan berbagai konsekuensinya. Jika ia menghendaki hidupnya itu baik, ia harus memperhatikan

\footnotetext{
"Ibid.

Itid., hlm. 216.

41 Ibid. hlm. 161.

4 Ibid, blrs, 160 .

43 Calvin, op.cit, hlm. 266.
} 
isyarat dari Allah, tetapi jika ia mendengar isyarat dari iblis, maka hidupnya akan rusak.

Tetapi bagi Augustinus, Allah begitu mengasihi manusia sehingga Ia tidak membiarkan manusia itu hancur. Allah menurut Augustinus, "... will not be angry with us forever, for you have mercy on earth and ashes, and it has been pleasing in your sight to reform my deformities." 44 Allah berkenan memperbaiki keberadaan manusia yang telah rusak tersebut. Kasih sayang (mercy) Allah yang besar itu telah dinyatakan-Nya dengan berkenan memberikan FirmanNya (Yesus Kristus) menjadi daging dan diam di antara manusia, dan anugerah (grace) Allah tersebut ditujukan kepada orang-orang yang rendah hati. ${ }^{45}$ Bagi Augustinus, Allah di dalam Anak-Nya Yesus Kristus berkenan membuka jalan keselamatan kepada kehidupan yang akan datang bagi manusia. ${ }^{46}$ Karena itu, Augustinus menegaskan bahwa anugerah Allah-lah yang mendahului pekerjaan yang baik pada manusia. Kemauan manusia untuk melakukan yang baik mengikuti dan menuruti anugerah Allah tersebut, bukan memimpin atau mendahului anugerah Allah tersebut. ${ }^{47}$ Penegasan Augustinus ini didasarkan pada ajaran Alkitab yang menggambarkan sukacita di surga dan di dunia jika orang yang berdosa bertobat dan diselamatkan. Allah menurut Augustinus, tidak berkenan manusia menemui kebinasaannya, tetapi melalui anugerah-Nya di dalam Yesus Kristus Allah berkenan menyediakan keselamatan bagi manusia yang telah rusak (korup) untuk memperoleh pengampunan dan hidup kekal dengan jalan pertobatan dan menanggapi anugerah dan kemurahan Allah itu dengan rendah hati dan memberikan hidupnya dituntun oleh Roh Kudus.

\footnotetext{
${ }_{45}^{44}$ Augustinus, op.cit., hlm. 168 .

${ }^{45}$ Ibid.

${ }^{46}$ Ibid., hlm. 167.

${ }^{47}$ Calvin., op.cit., hlm. 256.
} 


\section{John Calvin}

Calvin secara luas menjelaskan bagaimana manusia yang korup ini. Seperti Augustinus, Calvin menilai bahwa manusia itu korup (rusak) berawal dari dosa asali/turunan (original $\sin$ ) yang diwarisi manusia sebagai keturunan Adam. ${ }^{48}$ Bagi Calvin, dosa yang dilakukan oleh Adam mengakibatkan ia mengalami keterpisahan dengan Allah. Keterpisahan itu menyebabkan Adam menanggung hukumannya, yakni kematian jiwa dan berbagai penderitaan lainnya. Tetapi bukan hanya Adam yang menanggung resiko dari perbuatannya tersebut. Akibat pemberontakannya itu, seluruh tertib alam semesta juga menjadi rusak. Bahkan akibat dosa Adam itu jugałah, seluruh keturunan Adam ikut terjerumus ke dalam berbagai penderitaan. Jadi menurut Calvin, yang disebutkan oleh para Bapa Gereja dengan Dosa Asali adalah membusuknya kodrat yang pada mulanya baik dan murni.

Manusia yang rusak (korup) itu menurut Calvin bukan disebabkan oleh kodratnya (nature), olch suatu subtansi pada diri manusia sejak awal, tetapi disebabkan oleh kejahatannya (natural viciousness) yang menyebabkan kejatuhannya. ${ }^{49}$ Calvin menjelaskan bahwa dosa asali, yang awal kerusakannya pada diri Adam tersebut, kemudian mewariskan kerusakan (korup) tersebut terus-menerus dari orangtua kepada anak-anak dan cucu-cucu mereka. Hal itu dibaratkan oleh Calvin dengan akar yang busuk (korup), yang menghasilkan cabang-cabang yang busuk pula lalu menyebarkan kebusukan tersebut ke semua rantingnya. Jadi Calvin mendefinisikan dosa turunan sebagai " $a$ hereditary corruption and depravity of our nature" suatu kerusakan dan kebejatan pada kodrat kita yang bersifat turun-temurun. Dengan demikian, bagi Calvin, dosa asali menyebabkan kita semua sebagai keturunan Adam mengalami kerusakan (korup) dan kebcjatan kodrat yang menguasai semua bagian

\footnotetext{
${ }^{45}$ Calvin, lac cit.

${ }^{4}$ Boid. hirn. 219.
} 
jiwa kita sehingga di dalam diri kita timbul keinginan untuk melakukan apa yang disebut oleh Paulus sebagai perbuatan daging (Gal. 5:19). Kerusakan (korup) pada diri manusia oleh dosa tersebut menurut Calvin telah menguasai seluruh jiwa manusia, termasuk pikiran, hati, dan juga kemauannya. ${ }^{50}$ Manusia yang telah rusak (korup) oleh kejatuhannya tersebut selalu terdorong untuk melakukan yang jahat oleh kemauan dan nafsunya sendiri, bukan karena sesuatu dari luar. Begitu buruknya kodrat manusia tersebut sehingga ia tidak dapat berbuat yang lain kecuali melakukan yang jahat. Karena itu, bagi Calvin, manusia memang tidak bisa tidak harus berdosa. Calvin menurjuk pada kutipan Paulus dalam Roma 3:10, "Tidak ada yang benar, seorang pun tidak." Dengan mengutip ayat ini, Calvin maksudkan tidak hanya supaya manusia itu bertobat, tetapi lebih dari itu untuk mengajarkan bahwa semua orang akan ditimpa oleh malapetaka, dan karena itu mercka hanya dapat dibebaskan dari malapetaka tersebut "by the mercy of God." Hanya kasih sayang (mercy) dan anugerah (grace) Allah, menurut Calvin, yang dapat menjadi obat untuk memperbaiki dan menyembuhkan kerusakan (korup) kodrat manusia akibat dosa. Manusia dapat melakukan kebenaran hanya jika hatinya dibentuk, diarahkan dan diperkuat oleh Allah. Calvin mengingatkan kita bahwa di tengah-tengah kerusakan (korup) kodrat itu masih ada suatu tempat bagi anugerah Allah, bukan untuk membersihkan kerusakan tersebut, melainkan untuk mengendalikannya. Melalui pemeliharaan-Nya (providence), Allah mengendalikan kodrat manusia yang rusak (korup) tersebut sedemikian rupa, sehingga kerusakan tersebut tidak terwujud dalam perbuatan manusia yang dipelihara oleh Allah tersebut. ${ }^{51}$ Hanya Allah sajalah yang dapat memperbaiki manusia yang telah rusak tersebut.

\footnotetext{
St Ibid, hlm. 216-218.

"Ibuid, hin. 250-252.
} 


\section{Penutup}

Sejarah peradaban manusia memperlihatkan kepada kita realitas bahwa persoalan dan praktik korupsi telah ikut mewarnai persoalan umat manusia, sejak zaman dahulu hingga sekarang ini. Sejarah ini juga memperlihatkan terjadinya pergeseran perspektif terhadap persoalan korupsi tersebut, di mana jika di zaman dulu, persoalan korupsi dianggap sebagai masalah yang biasa, bahkan menjadi suatu kebiasaan dan gaya hidup (life style). Keadaan ini disebabkan oleh lemahnya hukum dan lemahnya moral manusia. Namun di zaman kini, korupsi menjadi suatu persoalan atau kejahatan luar biasa (extra ordinary crime). Karena merupakan kejahatan yang luar biasa di masa kini, maka pendekatan hukum yang semakin tegas dan menimbulkan efek jera menjadi"strategi yang diterapkan di berbagai negara termasuk di Indonesia dewasa ini.

Masalah korupsi, bagaimanapun tidak cukup hanya dilihat sebagai persoalan hukum, yang karena itu ditangani dengan pendekatan hukum (langkah kuratif) untuk menghukum para pelaku korupsi. Masalah korupsi terlebih harus dilihat sebagai masalah moral atau masalah etis. Manusia melakukan korupsi dikarenakan timbul niat dan dorongan dari dalam dirinya untuk melakukan tindakan korupsi tersebut. Karena itu, masalah moral manusia mesti ditangani agar ia tidak tergoda untuk melakukan tindakan korupsi. Pendekatan etis-moral ini merupakan langkah pencegahan (preventif) terhadap masalah korupsi. Manusia sebagai pelaku korupsi mesti disadarkan secara moral agar ia tidak memiliki keinginan dan dorongan untuk melakukan korupsi. 
Referensi:

Alatas, S.H. Korupsi, Sifat, Sebab dan Fungsi (terj.). Jakarta: LP3ES, 1987. - Sosiologi Korupsi (terj.). Jakarta; LP3ES, 1981.

Anwary, S. Quo Vadis Pemberantasan Korupsi di Indonesia, Jakarta: ISEPS-AMRA, 2005.

Augustinus. The Confessions of St. Augustine (terj.). Garden City: Image Books, 1960.

Becker, Lawrence C. and Charlotte B. Becker (eds.), Encyclopedia of Ethics (Vol.D). New York: Routledge, 2001.

Borrong, R.P. Citra Umum Korupsi: Korupsi di Indonesia Dilihat dari Sudut Pandang Etika Kristen (tesis). Jakarta: STT Jakarta, 1983.

Calvin, John. Institutes of the Christian Religion (terj.). Grand Rapids: Wm. B. Eerdmans Publishing, 1989.

Fahlbusch, Erwin et al. (eds.), The Encyclopedia of Christianity (Vol. 1), Grand Rapids - Michigan: William B. Eerdmans Publishing Company, 1999.

Hamzah, Andi. Perbandingan Pemberantasan Korupsi di Berbagai Negara. Jakarta: Sinar Grafika, 2005.

Hastings, James (ed.). Encyclopaedia of Religion and Ethics (Vol. IV), New York: Charles Scribner's Sons, 1951.

Harahap, Krisna. Pemberantasan Korupsi Jalan Tiada Ujung. Bandung: Grafitri, 2006.

Hendriks, Herman. Keadilan Sosial dalam Kitab Suci (terj.). Yogyakarta: Penerbit Kanisius, 1990.

Houlden, J.L. Ethics and The New Testament. Edinburgh: T\&T Clark, 1992. 
Klitgaard, Robert. Membasmi Korupsi (terj.). Jakarta: Yayasan Obor Indonesia, cet. ke-2 2001.

Klitgaard, Robert dkk. Penuentun Pemberantasan Korupsi dalam Pemerintahan Daerah (terj.). Jakarta: Yayasan Obor Indonesia, 2002.

Langston, Richard L. Bribery and the Bible. Singapore: Campus Crusade Asia Limited, 1991.

Lubis, Mochtar, dan James C. Scott (penyunting), Bunga Rampai Korupsi, Jakarta: LP3ES, cet. ke-3 1995.

Lubis, Mochtar, dan Stott, James C. (penyunting), Korupsi Politik, Jakarta: Yayasan Obor Indonesia, 1993.

McWalters, Ian. Memerangi Korupsi, Sebuah Peta Jalan untuk Indonesia (terj.). Surabaya: Jawa Pos Books, 2006.

Myrdal, Gunnar. Asian Drama Vol.H. New York: Pantheon, 1968.

Tanthowi, Pramono U. dkk. (eds.). Membasmi Kanker Korupsi, Jakarta: PSAP Muhammadiyah, 2005. 